\title{
Cutaneous Eccrine Glands of the Foot Pads of the Rock Hyrax (Procavia capensis, Hyracoidea, Mammalia)
}

\author{
P. Stumpf U. Welsch \\ Department of Anatomy, Chair II, University of Munich, Germany
}

\section{Key Words}

Cutaneous glands - Eccrine glands . Hyracoidea . Procavia capensis

\begin{abstract}
In order to find correlations between skin gland morphology and specific ethological features, the cutaneous glands of the foot pads of Procavia capensis were studied by histological and various histochemical methods and by electron microscopy. In the foot pads, abundant specific eccrine skin glands occur, which consist of coiled tubular secretory portions and coiled ducts. The wall of the secretory part is composed of cuboidal glandular cells and myoepithelial cells. Among the glandular cells two types occur: clear and dark cells. Clear cells have numerous mitochondria and form a basal labyrinth, indicating fluid transport. Dark cells, which stain strongly with periodic acid-Schiff, contain a highly developed perinuclear Golgi apparatus, large amounts of rough endoplasmic reticulum and many secretory granules indicating production of glycoproteins. Cytokeratin (CK) 19 was found in secretory compartments and ducts, CK14 only in duct cells. Single cells of the secretory coils and ducts may be stained with antibodies against antimicrobial peptides. Some glandular cells contain proliferating cell nuclear antigen-positive nuclei especially in the
\end{abstract}

\begin{tabular}{ll}
\hline KARGER & ( 2002 S. Karger AG, Basel \\
Fax $+41613061234-6405 / 02 / 1713-0215 \$ 18.50 / 0$ \\
$\begin{array}{l}\text { E-Mail karger@karger.ch } \\
\text { www.karger.com }\end{array}$ & $\begin{array}{l}\text { Accessible online at: } \\
\text { www.karger.com/journals/cto }\end{array}$
\end{tabular}

ducts indicating an increased cell proliferation. Terminal transferase (TdT)-mediated d-UTP nick-end labeling-positive nuclei can be detected predominantly in the secretory coils and rarely in the transitional portions between ducts and end pieces. We suppose that proliferating cells migrate from the ducts to the secretory coils. The secretory product of the eccrine cutaneous glands seems to improve the traction between the foot pads of these animals and the steep and smooth rock formations among which they live. 


\section{Introduction}

The aim of the present study was to investigate the morphology of the cutaneous glands of the foot pads of the rock hyrax (Procavia capensis, Hyracoidea, Mammalia) by various light-microscopic techniques and by transmission electron microscopy. The existence of these glands has been described so far only on the basis of museum specimens [Hahn, 1959].

Rock hyraxes occur at rocky cliffs or rock outcrops with cavities sufficient to shelter a colony. They are mammals, well adapted to arid environments, being found even in the mountains of the Namib, Sahara, and Arabian desert [Estes, 1992]. Hyracoidea originated in Africa and on the basis of morphological features are related to manatees (Sirenia) and elephants (Proboscidea) [Hahn, 1959; Kleinschmidt et al., 1986; Skinner and Smithers, 1990; Mills and Hes, 1997]. This was confirmed recently by comparison of the mitochondrial DNA sequences among these animals [Ozawa et al., 1997]. Hyracoidea attracted again specific interest since van Dijk et al. [2001] included them in their superorder Afrotheria on the basis of nuclear DNA sequences. Comparative molecular studies are valuable since they can challenge morphology and shed new light on phylogenetic connections. With these new molecular data in mind we studied the foot glands of the rock hyrax.

The foot pads of Procavia have a muscle arrangement that retracts the middle of the sole; forming a hollow that is a suction cup of considerable clinging power [Nowak, 1991]. The thick skin is endowed with abundant glandular tissue, the exudation of these glands serves to keep the surface permanently moist and is claimed to increase traction [Mills and Hes, 1997]. These functional and structural properties apparently allow the rock hyrax to move safely on steep and often smooth rock faces with agility. The density of the plantar glands of rock hyraxes is more than 10-fold higher if compared to those of human feet [Hahn, 1959]. Furthermore, many aspects of the Procavia ethology seem to be correlated with its relatively poor thermoregulatory ability; the body temperature of Procavia fluctuates relative to ambient temperature [Kingdon, 1971].

Different types of eccrine sweat glands are found in many mammals and have been described in detail [Schaffer, 1940; Terzakis, 1964; Johnson and Elizondo, 1974; Kurosumi et al., 1982; Tsukise et al., 1988; Marcucci and Castano, 1990; Meyer and Tsukise, 1995]. A careful study of the Procavia skin glands is lacking, and in order to correlate glandular morphology with the hyrax mode of life we investigated these skin glands.

\section{Materials and Methods}

\section{Animals}

Tissue samples of fore- and hind-feet of 2 adult female and 1 adult male $P$. capensis were collected for light and electron microscopy in the Northern Cape Province of the Republic of South Africa. The animals had been sacrificed for endocrinological research done by other scientists. The tissue samples were excised immediately after death and transferred either into phosphate-buffered 3.5\% formalin for light microscopy or into phosphate-buffered 3.5\% glutaraldehyde for electron microscopy and stored for 2 weeks. Principles of animal care and specific national laws were followed.

\section{Light Microscopy}

The material was fixed in phosphate-buffered formalin, embedded in Paraplast, sectioned, and stained with hematoxylin-eosin and Masson's trichrome stain for general orientation. In addition, the following histochemical reactions were applied: the periodic acid-Schiff (PAS) reaction and Alcian blue $\mathrm{pH} 1.0$ and pH 2.5 [Romeis, 1989].

The following lectins were applied for binding tests: wheat germ agglutinin (WGA), Helix pomatia agglutinin (HPA), Ulex europaeus I agglutinin (UEA I), peanut agglutinin, Canavalia ensiformis agglutinin, Ricinus communis agglutinin (RCA I), soybean agglutinin, Lens culinaris agglutinin and Wisteria floribunda agglutinin (WFA).

These lectins have the following sugar specifities: WGA for Nacetyl-glucosamine, soybean agglutinin, HPA and WFA for N-acetylgalactosamine, UEA I and L. culinaris agglutinin for fucose, peanut agglutinin for galactose, C. ensiformis agglutinin for mannose and glucose and RCA I for galactose and $\mathrm{N}$-acetyl-galactosamine.

Sections were incubated with biotinylated lectins followed by peroxidase-conjugated streptavidin and then 3,3-diaminobenzidine (DAB) as chromogen. The lectins were used according to the methods given by Goldstein and Poretz [1986]. They were obtained from Medac (Hamburg, Germany) and Sigma (Deisenhofen, Germany).

To demonstrate the presence of three subtypes of cytokeratins (CK), immunohistochemistry was performed by using the following working dilutions of monoclonal antibodies to the relevant human proteins: anti-CK7 (DAKO, Germany) 1:100, anti-CK14 (Serotec, UK) 1:10 and anti-CK19 (Boehringer Mannheim, Germany) 1:20. Sections were preincubated with $0.2 \%$ trypsin at $37^{\circ} \mathrm{C}$ for $15 \mathrm{~min}$, except for anti-CK14, which required antigen retrieval by microwave heating in citrate buffer. Immunoreactivity of the primary antibodies was visualized by using biotinylated goat anti-mouse IgG (Sigma) dilution 1:200 to 1:400, followed by peroxidase-conjugated streptavidin (DAKO) and DAB as the chromogen. The specificity of the primary antibodies was demonstrated in human tissues, such as skin, colon, and bronchi, in which they showed the typical CK pattern [Moll et al., 1982; Purkis et al., 1990].

For the detection of human $\beta$-defensins 1 and 2 monoclonal antibodies from Dr. R. Bals, Munich, were used at a working dilution of 1:100. Sections were preincubated with $0.2 \%$ trypsin at $37^{\circ} \mathrm{C}$ for $10 \mathrm{~min}$ or pretreated with microwave irradiation for $20 \mathrm{~min}$. The primary antibody was detected by using biotinylated goat anti-mouse IgG (Sigma) 1:200, followed by peroxidase-conjugated streptavidin (DAKO) 1:400 and DAB as the chromogen. The specificity of the primary antibodies was demonstrated in human tissues, such as liver and lung.

Polyclonal antibodies against adrenomedullin were obtained from Dr. A. Martinez (National Cancer Institute, Bethesda, Md., USA) and used at a working dilution of 1:1,000. Sections were pre- 
treated with microwave irradiation in citrate buffer at $\mathrm{pH} 6$ for $20 \mathrm{~min}$. For visualization a biotinylated swine anti-rabbit IgG antibody (DAKO) dilution 1:400 followed with DAB as the chromogen were applied.

Monoclonal antibodies against lysozyme (DAKO) 1:500 followed by biotinylated swine anti-rabbit IgG and then 3-amino-9-ethylcarbazole as the chromogen were used to detect muramidase, and monoclonal antibodies to the proliferating cell nuclear antigen (PCNA, cyclin; DAKO) at a working dilution of 1:200 were employed for immunohistochemical detection of proliferating cells. The sections were subjected to two pretreatments with microwave irradiation in citrate buffer at $\mathrm{pH} 6.0$ for $10 \mathrm{~min}$. The primary antibody was detected by using biotinylated goat anti-mouse $\operatorname{IgG}(1: 1,000$, Sigma). For visualization by light microscopy, a peroxidase-conjugated antibody (Boehringer Mannheim) followed by DAB was used. Positive controls were performed by using human and Procavia small intestine. Negative controls were treated equally by replacing the primary antibody by irrelevant mouse antibodies or non-immune mouse serum.

For in situ detection of cell death the terminal transferase (TdT)mediated d-UTP nick-end-labeling (TUNEL) procedure was performed on dewaxed paraffin sections according to Gavrieli et al. [1992] with the modifications described by Welsch et al. [1998b].

All light-microscopic preparations were photographed with an Olympus photomicroscope (BH-2) and planapochromate objectives on Agfa Pan 25 black and white film.

\section{Electron Microscopy}

Tissue samples $1-2 \mathrm{~mm}$ in size were transferred for $3 \mathrm{~h}$ into cooled $3.5 \%$ phosphate-buffered glutaraldehyde and thereafter stored in $1 \%$ phosphate-buffered glutaraldehyde until further processing. Prior to embedding in Araldite, the samples were post-fixed in $2 \%$ buffered osmium tetroxide for $2 \mathrm{~h}$. Semithin sections were stained with methylene blue-azur II for general orientation; thin sections were stained with uranyl acetate (saturated solution in $70 \%$ methanol) and lead citrate and viewed in a Philips CM 10 electron microscope operating at $80 \mathrm{kV}$.

\section{Results}

\section{General Morphology of the Skin and Skin Glands}

All integumental areas of the foot pads studied have a similar histological structure and consist of epidermis, dermis and hypodermis. The uppermost layer of the epidermis consisted of a 450- to 1,100- $\mu$ m-thick superficial horny layer (stratum corneum). The following stratum granulosum is composed of 2-3, and the stratum spinosum of 8-12 layers of squamous cells (fig. 1a). In the stratum basale we found abundant melanocytes containing large melanosomes. Long and branched dermal papillae at the dermoepidermal junction can be correlated to the considerable mechanical stress exerted on the skin. These papillae consist of loose connective tissue containing abundant blood capillaries. Underneath the narrow stratum papillare followed a thick layer of dense connective tissue representing the dermal reticular layer consisting of coarse collagen fibers, interwoven with elastic fibers. In this area of the skin the excretory ducts of the glands were usually strongly coiled. The ducts were lined by a two-layered epithelium and enveloped by a thick basement membrane. The glandular portions of the skin glands were located in the hypodermis and were composed of glandular cells, resembling those of eccrine glands (fig. 1b, c). The glandular epithelial cells were of similar height, reaching about $25 \mu \mathrm{m}$ in longitudinal diameter. The secretory cells contained slender or oval nuclei with a mean diameter of $7 \mu \mathrm{m}$. In semithin sections, these nuclei showed two or three nucleoli. Two types of glandular cells could be discerned. The adjacent fusiform myoepithelial cells lying on the basement membrane showed extensive branching. The width of the glandular lumen ranged from 12 to $45 \mu \mathrm{m}$ among different glands. The density of the glandular tubules was up to $300 / \mathrm{cm}^{2}$. Secretory segments were strongly coiled and were surrounded by adipose and connective tissue which contained nerves, blood capillaries, lymphatic capillaries, some mast cells, plasma cells, macrophages and eosinophils. Small groups of glands, embedded in adipose tissue, were delimited by connective tissue septa (fig. 1c) containing predominantly collagen and single elastic fibers. Relatively frequently Pacinian corpuscles (fig. 1d), sometimes in groups, occurred in the hypodermis. Nerve fibers with functional endings at the glands could be detected with transmission electron microscopy. Blood capillaries of varying size and with a continuous endothelium were common at the base of the glandular epithelium. The distance between the base of the glandular cells and the blood capillaries measured in general 2$3 \mu \mathrm{m}$. The tissue samples showed no sex differences. Apocrine and sebaceous glands were not found.

\section{PAS Reaction and Alcian Blue (pH 2.5 and 1)}

In all tissues investigated, the PAS reaction of glandular cells revealed the presence of two cell types: clear and dark cells. Clear cells were very weakly stained by PAS, especially along their apical membrane. Dark cells were marked by a strong staining of the whole cytoplasm; in the perinuclear zones prominent granules can occur, which were PAS positive (fig. 2a, b). PAS-positive material inside the glandular lumen could not be detected. Myoepithelial cells were weakly stained, and the basement membranes of the glandular tubules were strongly PAS positive. The connective tissue matrix showed a weak positive PAS reaction.

Alcian blue stained the secretory compartments of the glands stronger than the ducts. The basement membranes of glandular tubules were strongly stained with Alcian blue $\mathrm{pH} 2.5$, while at $\mathrm{pH} 1$ Alcian blue gave negative 

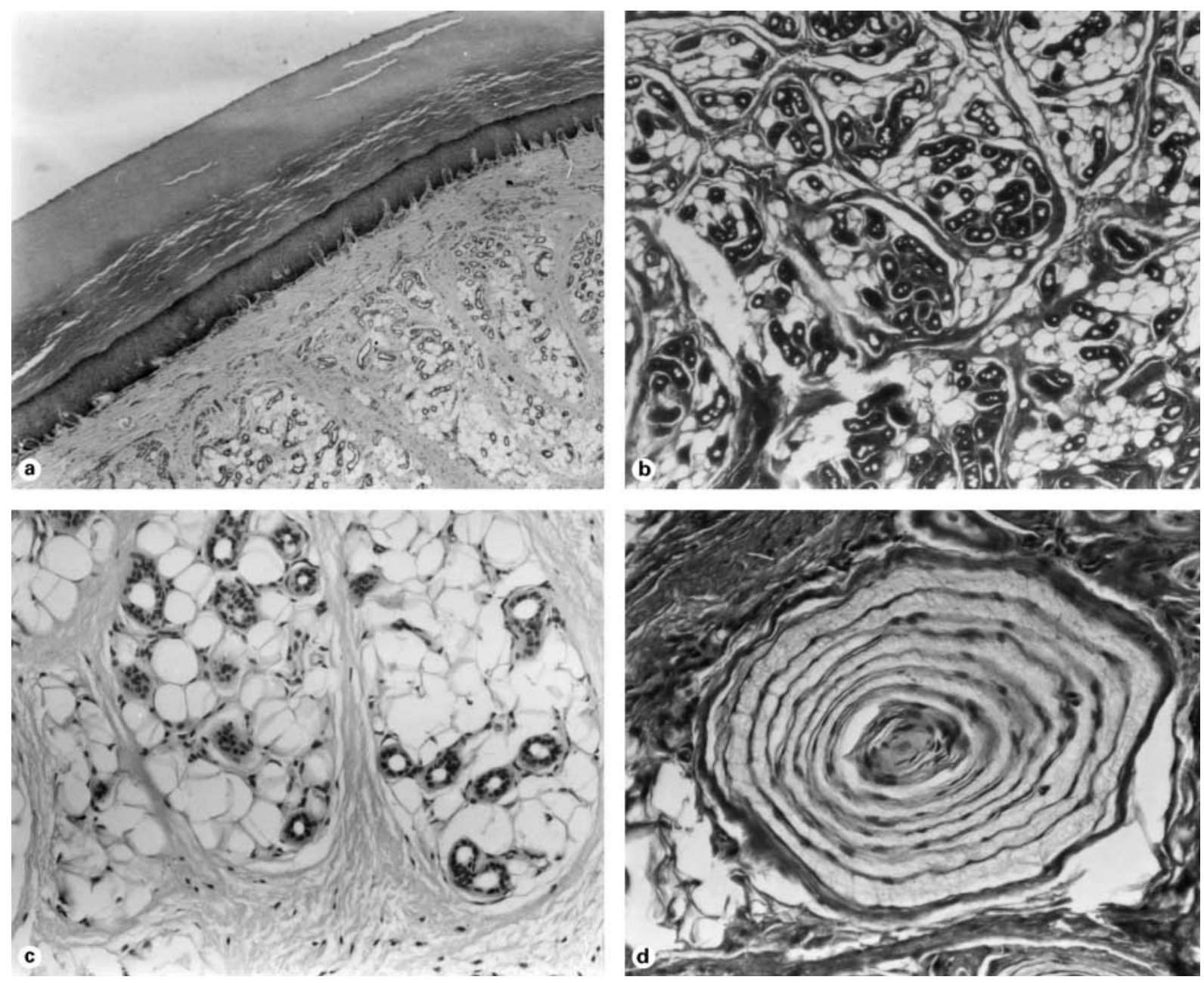

Fig. 1. General morphology of the skin and skin glands. a Low-power micrograph of the whole skin with epidermis, dermis and hypodermis. HE. $\times 32$. b Low-power micrograph of a skin area with abundant glands, which is separated by connective tissue containing predominantly collagen fibers. Masson's trichrome stain. $\times 56$. c Deeper area of the skin containing loosely packed glandular tubules in the adipose tissue. HE. $\times 140$. d Pacinian corpuscles in the hypodermis. Masson's trichrome stain. $\times 145$.

results in all investigated glands. The apical membranes of secretory cells were moderately stained with Alcian blue $\mathrm{pH} 2.5$ (fig. 2c). The lumen of the tubules sometimes contained positively stained secretory material. The connective tissue was weakly stained with Alcian blue $\mathrm{pH} 1$ and with medium intensity at $\mathrm{pH} 2.5$. Single cells, interpreted to be mast cells, were intensely stained.

\section{Lectins}

We observed a moderate staining of the apical cell membrane of secretory cells with HPA. In some secretory cells the entire cytoplasm showed a faint binding of HPA. The apical cell borders of the duct cells had only few binding sites for this lectin.
WFA, RCA I and WGA stained the apical cell membranes of secretory coils and ducts (fig. $2 \mathrm{~d}-\mathrm{f}$ ). In single secretory cells the entire cytoplasm was moderately stained with WFA (fig. 2d).

Fig. 2. Carbohydrate histochemistry. a Secretory coils with clear and dark cells. Note the separating connective tissue. PAS stain. $\times 305$. b Secretory coils. The apical membranes of secretory cells are weakly stained. Arrows indicate dark cells. PAS stain. $\times 780$. c Several glandular tubules. The apical membranes of secretory cells are moderately stained with Alcian blue $\mathrm{pH} 2.5$. $\times 320$. d Positive reaction of secretory cells and duct cells. Intensive staining of the perinuclear cytoplasm of some secretory cells. WFA. $\times 370$. e RCA I binding of the apical membranes of secretory cells. $\times 360$. $f$ The apical cytoplasm of secretory cells is marked by the lectin WGA. $\times 335$. 

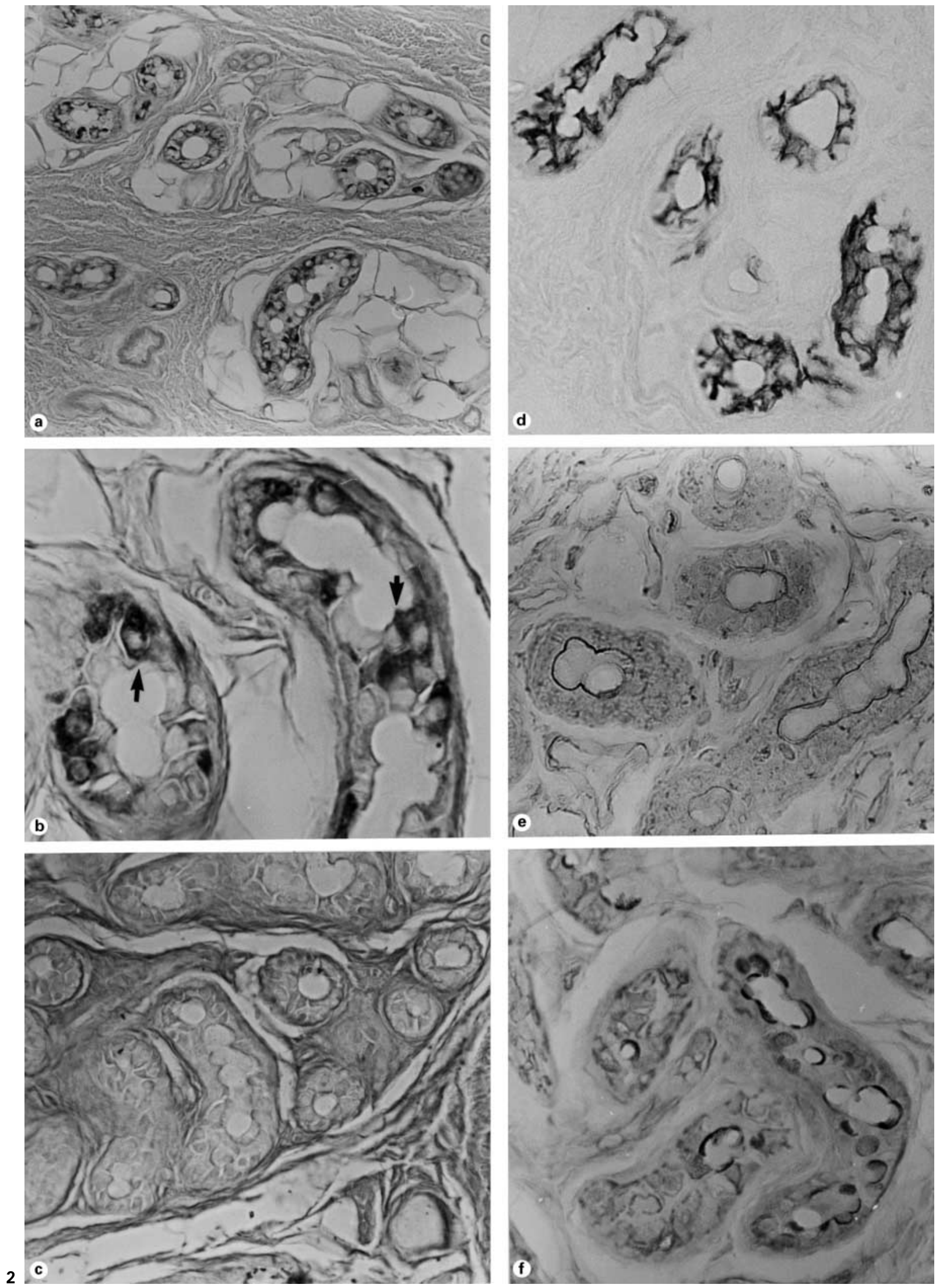

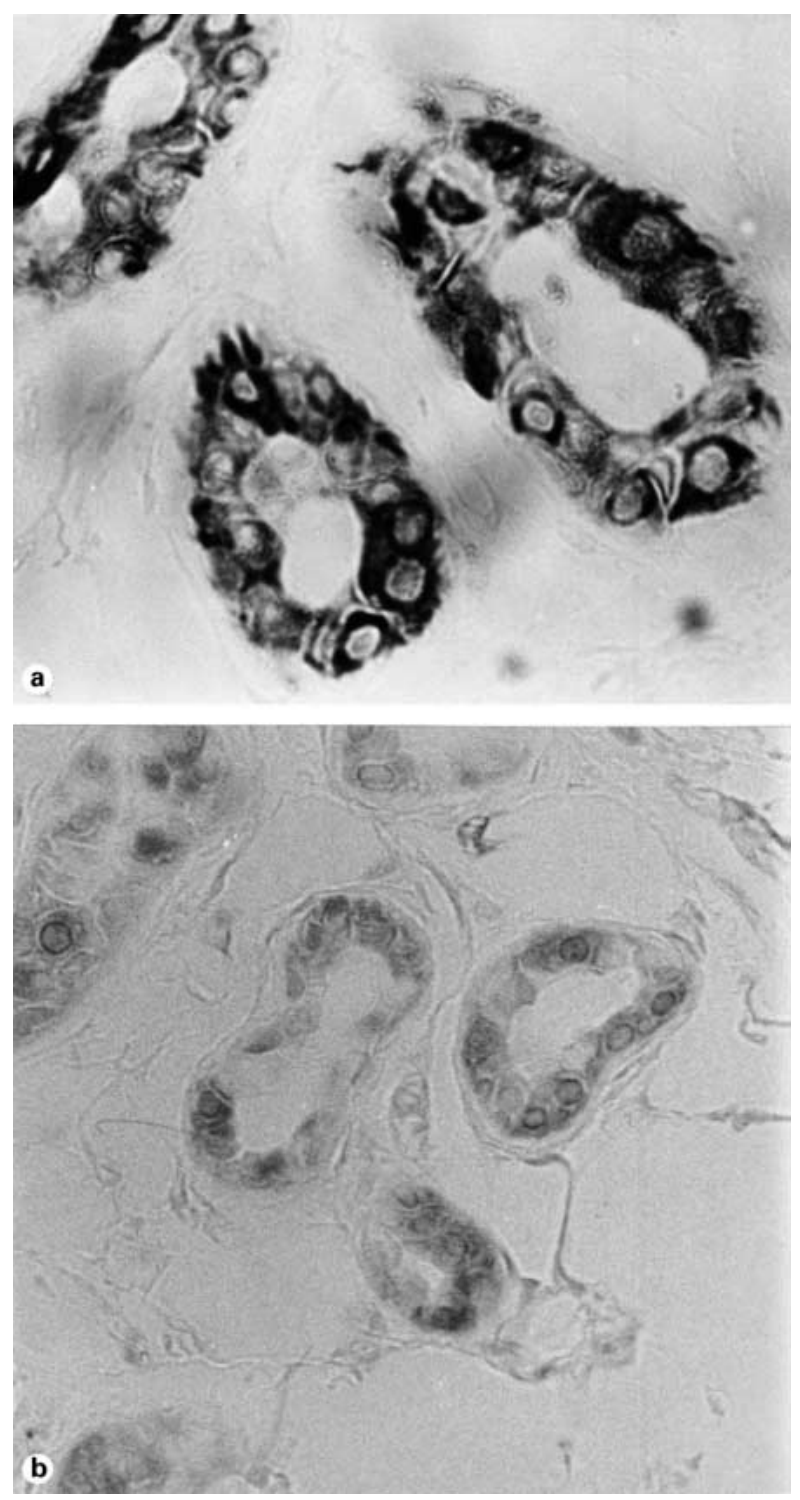

Fig. 3. Cytokeratins and adrenomedullin. a Heterogenous expression of CK19 in the whole cytoplasm of secretory cells. $\times 750$. b Anti-adrenomedullin immunoreactivity of secretory coils and ducts. The whole cytoplasm is moderately stained. $\times 510$.

The glands showed a faint cytoplasmic binding of $L$. culinaris agglutinin and soybean agglutinin. The glandular cells did not react with UEA I, peanut agglutinin and C. ensiformis agglutinin.

\section{Cytokeratins}

Immunohistochemical staining of the Procavia skin glands for CKs was markedly positive only in the case of CK19. The compartments of the glands reacted with dif- ferent intensities. Single cells of secretory coils showed intense reactions of the whole cytoplasm (fig. 3a) to both clear and dark cells. The cells of the secretory ducts were moderately stained. The cytoplasm of the duct cells was stained predominantly in the perinuclear zone and in the apical compartment. In the adjacent basal epidermis we found cells in clusters expressing CK19 indicating the presence of Merkel cells [Wollina, 1990a]. A weak staining with antibodies against CK14 was observed in luminal and peripheral cells of the ducts with some differences among the tissue samples. Clear and dark cells of secretory coils were always negative. Myoepithelial cells did not show any immunoreactivity in contrast to myoepithelial cells of eccrine glands of other species. Antibodies against CK7 did not react with Procavia tissue samples.

\section{Adrenomedullin-, Lysozyme- and Human $\beta$-Defensin Immunoreactivity}

A weak to medium intense reaction of all glandular cells could be detected with antibodies against adrenomedullin (fig. 3b). Staining was also positive in the cells of the ducts. Anti-adrenomedullin immunoreactivity was sometimes stronger in the cellular apex than in the basal parts of the cells.

Anti-lysozyme staining was localized at the apical membranes of secretory cells and the material inside the glandular lumen showed sometimes a weak positive reaction. A faint staining of the whole cytoplasm of some secretory cells was observed. The cells of the ducts remained unstained with antibodies against lysozyme.

In the glands of Procavia the expression of human $\beta$ defensin 1 and 2 was variable and generally weak. One glandular cell with stronger reactivity could alternate with cells showing weak degrees of human $\beta$-defensin expression.

\section{Proliferation and Apoptosis}

For the detection of the S-phase of proliferating cells, tissue sections were stained with PCNA. All investigated areas of the skin showed a higher density of positive nuclei in the ducts and in the transitional zone between ducts and secretory portions if compared with the secretory coils. Positive nuclei of two neighboring cells (fig. 4a) could be detected in up to $5 \%$ of all positive cells. Only the peripheral cells of the ducts showed a positive nuclear staining in accordance with the differentiation process. The nuclei of adjacent myoepithelial cells were always negative. High proliferating activities of whole glands were not observed. 
To identify programmed cell death, we localized apoptotic nuclei by the TUNEL reaction. Positive nuclei, sometimes grouped together, were found predominantly in secretory coils (fig. 4b). They were scored in up to four microscopic fields of each tissue sample at a magnification of 40 times. These positive cells showing chromatin condensation were scattered randomly over large areas of the skin. Nuclei of myoepithelial cells were always negative. In the adjacent epidermis we observed TUNEL-positive nuclei only in the uppermost layer of the stratified epithelium.

\section{Ultrastructure}

The ultrastructural analysis confirmed the presence of three types of cells in the secretory coils: (1) dark cells, (2) clear cells and (3) spindle-shaped myoepithelial cells directly adjacent to the basement membrane (fig. 5a).

Clear cells always showed highly developed lateral interdigitations as well as similar narrow infoldings of their basal membranes near blood capillaries (fig. 6a, b). These cells contained a large amount of mitochondria of the crista type with a maximal length of $2.5 \mu \mathrm{m}$. The highest densities of mitochondria were found in the basal cytoplasm. Also in the basal cytoplasm of these cells we detected small homogeneous electron-dense granules grouped together with a mean diameter of $45 \mathrm{~nm}$. The perinuclear compartment and the periphery of clear cells contained cytoskeletal components in the form of small bundles of intermediate filaments $(10-12 \mathrm{~nm})$ and thin filaments $(7 \mathrm{~nm})$, the latter being associated with apical membranes and microvilli. Microtubules were rarely detected, they were located mainly in the neighborhood of centrioles radiating into the cellular periphery. Lysosomal bodies showed high variations in size, structure and density and were predominantly associated with the supranuclear cytoplasm and with the Golgi apparatus.

Dark cells contained a prominent Golgi apparatus and numerous fields of the rough endoplasmic reticulum of various sizes throughout the cytoplasm with the highest densities in the basal and the lateral compartments. The microvilli of the dark cells were approximately $30 \%$ longer than those of the clear cells. The microvilli of the two cell types showed a surface coat. The dark cells had less mitochondria, but significantly more polysomes in their cytoplasm than the clear cells. They contained variable numbers of secretory vesicles with diameters up to $80 \mathrm{~nm}$ (rarely up to $110 \mathrm{~nm}$ ) and heterogeneous lysosomal bodies. Typical glycogen particles (predominantly $\beta$ particles) were found in both cell types. Clear and dark cells were apically interconnected by tight junctions (fig. 6c), inter-

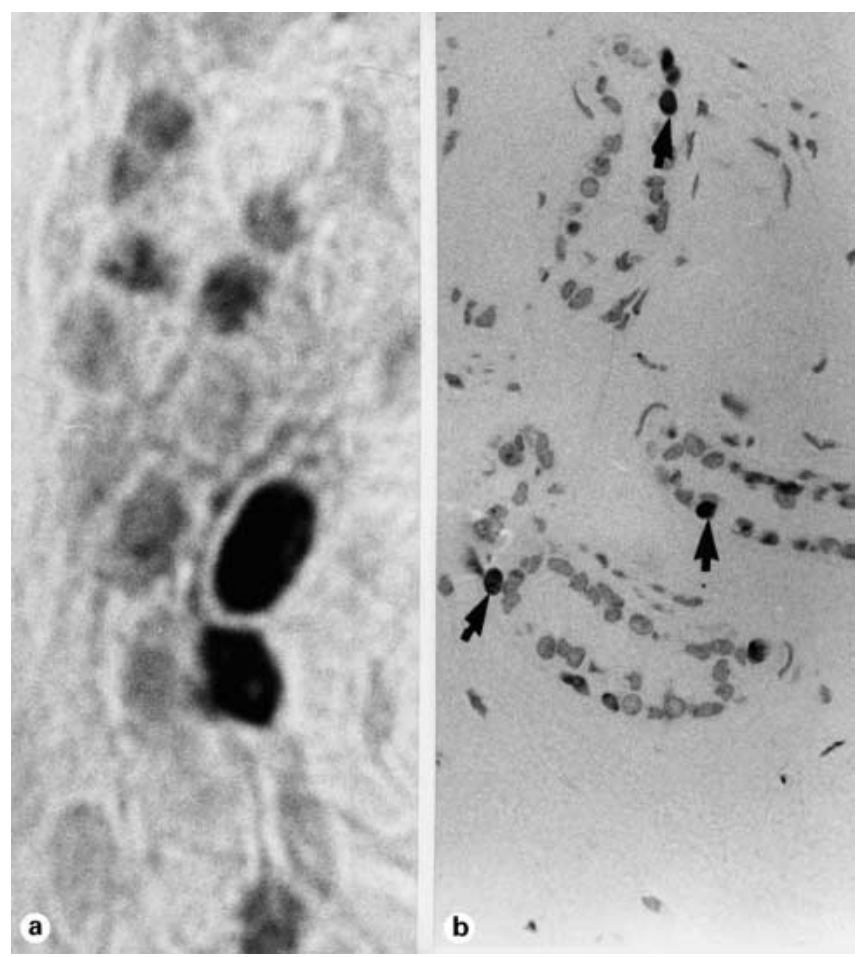

Fig. 4. Proliferation and apoptosis. a PCNA-positive nuclei of two basal cells of a coiled duct. $\times 960$. b Several glandular tubules with apoptotic nuclei. Only strongly stained nuclei are positive for TUNEL (arrows). $\times 350$.

mediate junctions, gap junctions and desmosomes, from which intermediate filaments spread into the cytoplasm.

Furthermore, in the secretory coils and more often in the transitional portions, cells with a large pale nucleus and a clear and homogeneous cytoplasm poor in organelles were noted, which may represent stem cells. The myoepithelial cells at the basement membrane were marked by densely packed myofilaments and extensive branchings. These cells were interconnected with the glandular epithelial cells by prominent desmosomes and among themselves by desmosomes and gap junctions, indicating electrical coupling. Near the myoepithelial and secretory cells, unmyelinated thin nerve fibers were often seen, either grouped in bundles or single, with a diameter of $0.5-1 \mu \mathrm{m}$ (fig. $5 \mathrm{~d}$ ).

The transitional portions between ducts and secretory portions (fig. 5b) contained more undifferentiated cells with a paler and more homogenous cytoplasm than in the secretory coils, a fact which is consistent with the PCNA reactivity described above. The ducts possess typical luminal and peripheral cells, both being relatively rich in mitochondria and intermediate filaments (fig. 5c). 

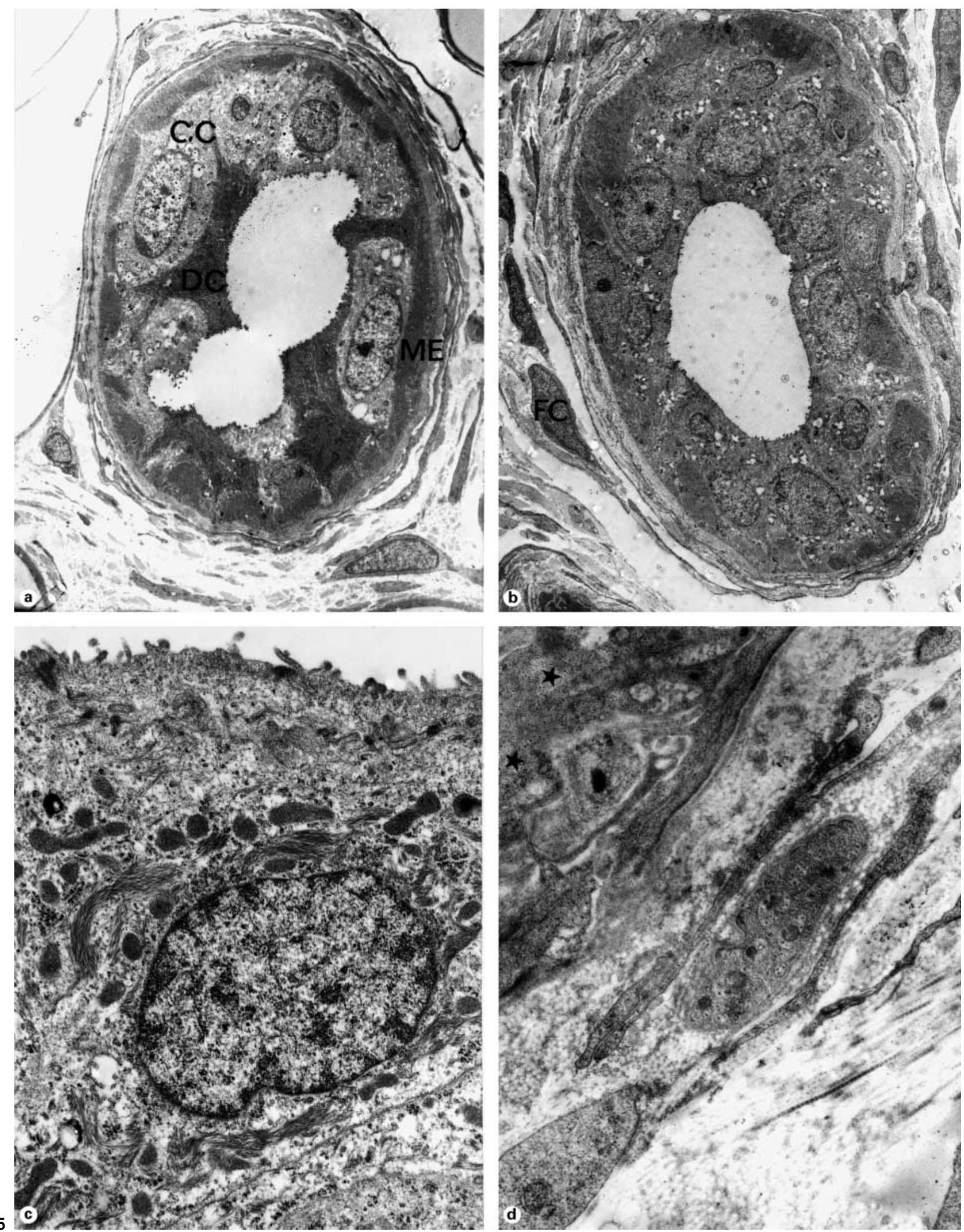

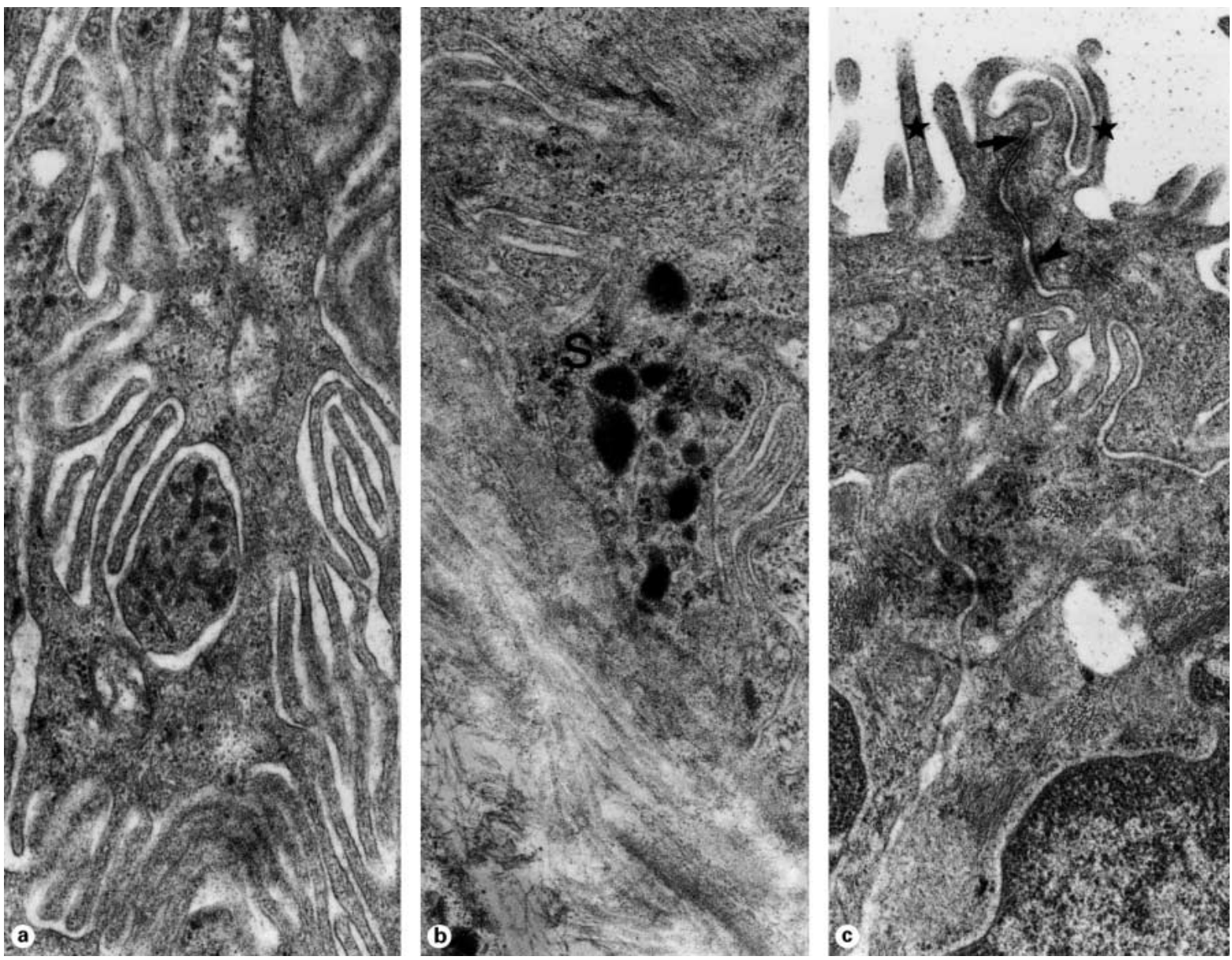

Fig. 6. Ultrastructure of the glands. a Membranes of neighboring clear cells with abundant interdigitating projections and narrow winding intercellular spaces. $\times 28,750$. b The basal part of a secretory cell. $\mathrm{S}=$ Secretory granules. $\times 28,750 . \mathbf{c}$ The apical parts of two dark cells with abundant microvilli (stars). Tight junction (arrow). Zonula adhaerens (arrowhead). $\times 31,050$

The connective tissue contained predominantly collagen fibers, but elastic fibers were also found. Directly adjacent to the basement membrane of the secretory coils, fibrocytes with a typical flattened shape were detected (fig. 5b).

Fig. 5. Ultrastructure of the glands. a Low-power magnification of a secretory coil consisting of two cell types. $\mathrm{CC}=$ Clear cells with numerous mitochondria; $\mathrm{DC}=$ dark cells with a highly developed Golgi apparatus; $\mathrm{ME}=$ myoepithelial cell. $\times 1,950$. b Cross-section of a transitional portion. The wall of the duct is consisting of two cell types, the outer or peripheral cells and the inner or luminal cells. Note the discontinuous layer of myoepithelial cells. $\mathrm{FC}=$ Adjacent fibrocyte. $\times 1,850$. c Luminal duct cell, rich in mitochondria and intermediate filaments. $\times 9,200$. d Unmyelinated nerve fibers in the connective tissue adjacent to the basement membrane. Neighboring secretory cell with abundant granules and glycogen particles in the basal cytoplasm (stars). $\times 17,200$.

Cutaneous Eccrine Glands of the

Foot Pads of the Rock Hyrax

\section{Discussion}

The present study has shown that the integument of the soles of fore- and hind-feet of the rock hyrax contains specific glands which occur in a unique density and which are embedded in connective tissue with abundant univacuolar adipose cells. These glands can be ascribed to only one type which we interpret to be eccrine.

The interpretation as eccrine cutaneous glands is based on the following observations: (1) the tubular glands consist of coiled end pieces with myoepithelial cells and coiled ducts, (2) the glandular cells do not form domeshaped apical protrusions and do not display striking differences in height and (3) two types of glandular cells (clear and dark cells) were found in the tubular end pieces. 
Thus, these glands closely resemble even the tubular eccrine glands of catarrhine primates including man. Since Schaffer [1940] and Starck [1982] have described the glands in the foot soles of rats and dogs to be apocrine glands, we want to stress the differences between eccrine and apocrine skin glands and thus underline our interpretation as eccrine glands in Procavia. Apocrine glands serve a pheromonal-olfactory function and are morphologically marked by the presence of only one glandular cell type. This cell type undergoes typical changes in height and pinches off apical cytoplasm as a peculiar and still poorly understood mode of secretion [Hashimoto et al., 1986; Aumüller et al., 1999].

The best known general function of cutaneous eccrine glands is their role in thermoregulation. Primate eccrine glands of palms and soles may have additional functions but they are no scent glands, which is underlined by the observation that prosimians urinate on their palms and thus mark branches of trees [Estes, 1992].

Comparing primate eccrine glands with those of Procavia two constant morphological differences are striking: the glandular lumen is wider in the hyrax glands $(16.5 \mu \mathrm{m})$ than in the glandular epithelium of primates $(5.5 \mu \mathrm{m}$ in Macaca mulatta, own observations) and the height of the glandular epithelium is always lower in Procavia than in primates. This may indicate a somewhat lower intensity of secretory activity of the individual glands at a given moment and a greater storage capacity of the secretory fluid, which in case of demand can be expelled in comparatively large quantities.

As in primates, the glands of the hyrax fore- and hindfeet contain two glandular cell types, which have been named here clear and dark cells. The morphology of the clear cells is that of fluid transporting cells (abundant mitochondria and well-developed basolateral membrane infoldings and numerous microvilli). These clear cells are very similar to those of primate clear cells in eccrine skin glands [Hashimoto et al., 1986]. The dark cells are secretory cells producing a glycoprotein, as indicated by the strong PAS positivity. At the electron-microscopic level a well-developed rough endoplasmatic reticulum and Golgi apparatus and secretory granules support this interpretation. Again, the dark cells of Procavia share these characters with the primate dark cells, in which the secretion of neutral mucoid substances has been described [Hashimoto et al., 1986]. Although exact data are lacking, it appears as though the dark cells are more frequent in Procavia eccrine glands than in those of primates.

The PAS reaction demonstrated (1) the presence of relatively large numbers of dark cells in the Procavia eccrine glands, and (2) that the secretory product is a neutral glycoprotein (glycogen is only a minor component in the dark cells).

The lectin binding studies of the Procavia foot pads, which were done with the concept of analyzing the glandular epithelium more specifically, revealed binding sites at the apical membrane of glandular cells for HPA, WFA, RCA I and WGA suggesting the presence of N-acetylgalactosamine, $\mathrm{N}$-acetyl-glucosamine and galactose. With the exception of single cells in WFA preparations we found no general cytoplasmic staining of the glandular cells. This is surprising in view of the strong PAS positivity of the entire cytoplasm of the Procavia dark glandular cells, which is assumed to reflect the presence of a secretory product. A future study using a more extensive panel of lectins may give a more specific characterization of the secretory product. It is of interest to note that RCA I and WGA also react with the apical membrane of the glandular cells of human sweat glands [Ookusa et al., 1983; Wollina et al., 1989], which would suggest a similarity in the composition of the glycocalyx of eccrine glands between Hyracoidea and primates. Skin glands of wolves [Meyer and Tsukise, 1995], pigs [Tsukise et al., 1983], goats [Tsukise et al., 1988] and cats [Meyer and Bartels, 1989] showed different lectin binding patterns, e.g. in the pig strong cytoplasmic staining by UEA I and WGA was observed. Such differences - if based on statistically sufficient numbers - indicate molecular evolutionary adaptations, the significance of which is still unclear. Furthermore, the possibility of blood group differences within one species needs to be considered.

The results of anti-adrenomedullin-, anti-lysozymeand anti-defensin immunoreactivity need to be interpreted with caution and can be regarded at present only as tentative results since the phylogenetic difference between humans and Hyracoidea is considerable and since nonspecific cross-reactions cannot be ruled out. The glands of the foot pads of Procavia seem to express adrenomedullin, a peptide with several different functions [Jahnke et al., 1997]. Adrenomedullin as a vasoactive hormone has potent hypotensive effects by inducing vasodilation [Nuki et al., 1993], inhibits the salt appetite and water drinking in the rat [Murphy and Samson, 1995] and may determine the fluid and electrolyte balance of Procavia because the glands of the foot pads may secrete considerable amounts of fluid. So adrenomedullin could play a role in the control of systemic and especially local circulation and also of fluid secretion in Procavia. An anti-microbial function of adrenomedullin is however more probable, which has been described by Walsh et al. [1996]. 
The antimicrobial activity of Procavia skin glands can also be associated with possible lysozyme (muramidase) and human $\beta$-defensin activity. The apical portions of secretory cells reacted with antibodies against lysozyme and sometimes we found intraluminal secretory products which were stained with antibodies against lysozyme. In humans, eccrine glands do not express lysozyme, but apocrine glands may have a bactericidal role [Ezoe and Katsumata, 1990].

The glandular epithelium, mainly the dark cells of Procavia, probably also expresses human $\beta$-defensin 1 and 2 with a broad antibacterial activity against many organisms which is synergistic with lysozyme [Bals et al., 1998]. The exudation of the glands of the foot pads serves to keep the skin permanently moist, which may cause a higher susceptibility to infections requiring an effective local defense system.

Antibodies against CK19 showed a strong reaction predominantly in the perinuclear zone of the cells of the secretory portion of the eccrine glands of Procavia, as is the case in the eccrine sweat glands of humans (own observations). Also, the cells of the ducts were stained in the apical compartments by using this antibody. In contrast, positive staining using antibodies against CK14 was only found in the duct cells. Basal cell expression of CK14 as in mixed epithelia [Purkis et al., 1990] or typical differences in the staining patterns of inner and outer cells of the ducts [Wollina et al., 1990b] were not found. The myoepithelial cells, usually expressing CK14 [Wollina et al., 1990b; Moll et al., 1982] did not show any reaction with CK14 in Procavia. Data concerning the cytokeratin expression in eccrine glands of the foot pads of pigs, wolves, dogs, cats and rats are not available. The immunoreactivity of CK7, CK14 and CK19 in the apocrine cutaneous glands of impalas [Welsch et al., 1998a] differs considerably from that in the Procavia glands. An interesting finding of the glands of Procavia was the occurrence of cells in the secretory compartment with a strong homogenous staining of the whole cytoplasm, an observation which has been described under pathologic conditions [Ichikawa et al., 1997].

The PCNA and TUNEL reaction allow insights into the cell turnover of the glands. Anti-PCNA labelled a few secretory cells and outer cells of the duct, myoepithelial cells were not stained as in other eccrine glands [Morimoto and Saga, 1995]. In contrast to human eccrine glands, we could not find any highly proliferative germinative cells in the transitional portions or the coiled ducts [Hagiwara and Shibasaki, 1994], but the density of positively stained nuclei was higher in these parts if compared to the secretory compartments.

Cutaneous Eccrine Glands of the

Foot Pads of the Rock Hyrax
Apoptotic nuclei as localized by the TUNEL reaction showed positive cells predominantly in the secretory segments of the glands. Compared to other tissues like the apical parts of villi in the small intestine or the uppermost layers of human epidermal tissues we observed an extremely low density of TUNEL-positive nuclei. Since we do not know anything about rhythmic periodicities in respect of cell replacement in the cutaneous glands of Procavia, the material studied is insufficient for definitive statements on frequency of apoptosis. We conclude that lost secretory cells are replaced by proliferating cells of the transitional portions and the coiled ducts.

Electron microscopy and carbohydrate histochemistry confirmed that the skin of the foot pads of Procavia contains glands of the eccrine type with clear and dark cells in the secretory coil having an unusual wide lumen. The high density of these glands in the foot pads may be an adaptation to the special environment of Procavia to ensure secure climbing up the steep rocks. In all investigated tissue samples the glands were embedded in adipose tissue beneath a thick reticular layer, an adaptation to the mechanical stress to which the foot pads are exposed. Immunolocalization of proliferating and apoptotic cells showed that the glands of Procavia are a slowly renewing tissue. We conclude that the main function of these glands is to improve the traction properties by secreting large amounts of fluid.

\section{Acknowledgments}

We are grateful to Prof. R. van Aarde, Pretoria, Republic of South Africa, for the gift of fresh skin material of $P$. capensis. We are greatly indepted to S. Herzmann, A. Kubacki, S. Tost, P. Unterberger and K. Verch for excellent technical assistance.

Cells Tissues Organs 2002;171:215-226 


\section{References}

Aumüller, G., B. Wilhelm, J. Seitz (1999) Apocrine secretion - Fact or artifact? Ann Anat 181 437-446.

Bals, R., X. Wang, Z. Wu, T. Freeman, V. Bafna, M. Zasloff, J.M. Wilson (1998) Human beta defensin 2 is a salt-sensitive peptide antibiotic expressed in human lung. J Clin Invest 102 . 874-880.

van Dijk, M.A.N., O. Madsom, F. Catzeflis, M.J. Stanhope, W.W. de Jong, M. Pagel (2001) Protein sequence signatures support the African clade of mammals. Proc Natl Acad Sci USA 98. 188-193.

Estes, R.D. (1992) The Behavior Guide to African Mammals. Berkeley, University of California Press, pp 250-258.

Ezoe, K., M. Katsumata (1990) Immunohistochemical study of lysozyme in human apocrine glands. J Dermatol 17: 159-163.

Gavrieli, Y., Y. Sherman, S.A. Ben-Sasson (1992) Identification of programmed cell death in situ via specific labeling of nuclear DNA fragmentation. J Cell Biol 119: 493-501.

Goldstein, I.J., R.D. Poretz (1986) Isolation, physicochemical characterization, and carbohydrate-binding specificity of lectins; in Liener, I.E., N. Sharon, I.J. Goldstein (eds): The Lectins. Orlando, Academic Press, pp 17-39.

Hahn, H. (1959) Von Baum-, Busch- und Klippschliefern. Wittenberg Lutherstadt, Ziemsen, pp 5-37.

Hagiwara, H., S. Shibasaki (1994) Electron microscopic observation of the transitional portion in the human eccrine sweat gland. Arch Histol Cytol 57: 67-76.

Hashimoto, K., K. Hori, M. Aso (1986) Sweat glands; in Bereiter-Hahn, J., A.G. Matoltsy, K. Sylvia Richards (eds): Biology of the Integument, Vertebrates. Berlin, Springer, vol 2, pp 339-356.

Ichikawa, E., S. Okabe, Y. Umebayashi, S. Ijima, F. Otsuka, S. Watanabe (1997) Papillary eccrine adenoma: Immunohistochemical studies of keratin expression. J Cutan Pathol 24: 564 570.

Jahnke, G.D., M.J. Miller, A. Martinez, L. Montuenga, F. Cuttitta (1997) Adrenomedullin expression in the mouse mammary gland: Evidence for the mature form in milk. J Mol Endocrinol 19: 279-289.

Johnson, G.S., R.S. Elizondo (1974) Eccrine sweat gland in Macaca mulatta: Physiology, histochemistry, and distribution. J Appl Physiol 37: 814-820.
Kingdon, J. (1971) East African Mammals. An Atlas of Evolution in Africa. I. London, Academic Press, pp 446-448.

Kleinschmidt, T., E. Czelusniak, M. Goodman, G. Braunritzer (1986) Paenungulata: A comparison of the hemoglobin sequences from elephant, hyrax, and manatee. Mol Biol Evol 3: 427-435.

Kurosumi, K., U. Kurosumi, H. Tosaka (1982) Ultrastructure of human eccrine sweat glands with special reference to the transitional portion. Arch Histol Jpn 45: 213-238.

Marcucci, A., P. Castano (1990) Eccrine sweat glands of rat fingertips. Scanning electron microscope observations after enzymatic digestion of dermal connective tissue. Acta Anat 137: 31-36.

Meyer, W., T. Bartels (1989) Histochemical study on the eccrine glands in the foot pad of the cat. Basic Appl Histochem 33: 219-238.

Meyer, W., A. Tsukise (1995) Lectin histochemistry of snout skin and foot pads in the wolf and the domesticated dog (Mammalia: Canidae). Anat Anz 177: 39-49.

Mills, G., L. Hes (1997) Southern African Mammals. Winchester, Striuck Winchester, pp 228229.

Moll, R., W.W. Franke, D.L. Schiller, B. Geiger, R. Krepler (1982) The catalog of human cytokeratins: Patterns of expression in normal epithelia, tumors and cultured cells. Cell 31: 11-24.

Morimoto, Y., K. Saga (1995) Proliferating cells in human eccrine and apocrine sweat glands. $J$ Histochem Cytochem 43: 1217-1221.

Murphy, T.C., W.K. Samson (1995) The novel vasoactive hormone, adrenomedullin, inhibits water drinking in the rat. Endocrinology 136 : 2459-2463.

Nowak, R.M. (1991) Walker's Mammals of the World, ed 5. Baltimore, Johns Hopkins University Press, vol 2, pp 1287-1292.

Nuki C., H. Kawasaki, K. Kitamura, M. Takenaya, K. Kangawa, T. Eto, A. Wada (1993) Vasodilator effect of adrenomedullin and calcitonin gene related peptide receptors in rat mesenteric vascular beds. Biochem Biophys Res Commun 196: 245-251.

Ookusa, Y., K. Takata, M. Nagashima, H. Hirano (1983) Distribution of glycoconjugates in normal human skin using biotinyl lectins and avidin-horseradish peroxidase. Histochemistry 79: $1-7$.

Ozawa, T., S. Hayashi, V.M. Mikhelson (1997) Phylogenetic position of mammoth and Steller's sea cow within Tethytheria demonstrated by mitochondrial DNA sequences. J Mol Evol 44: 406-413.
Purkis, P.E., J.B. Steel, I.C. Mackenzie, W.B.J. Nathrath, I.M. Leigh, E.B. Lane (1990) Antibody markers of basal cells in complex epithelia. J Cell Sci 97: 39-50.

Romeis, B. (1989) Mikroskopische Technik, ed 17 Munich, Urban \& Schwarzenberg, pp 441444.

Schaffer, J. (1940) Die Hautdrüsenorgane der Säugetiere; in Möllendorff W. v. (ed): Handbuch der mikroskopischen Anatomie des Menschen. Berlin, Urban \& Schwarzenberg, vol 2, pp 1464.

Skinner, J.D., R.H.N. Smithers (1990) The Mammals of the Southern African Subregion. Pretoria, University of Pretoria, pp 553-563.

Starck, D. (1982) Vergleichende Anatomie der Wirbeltiere. Berlin, Springer, vol 3, pp 201209.

Terzakis, J.A. (1964) The ultrastructure of monkey eccrine sweat glands. Z Zellforsch Mikrosk Anat 64: 394-509.

Tsukise, A., W. Meyer, R. Schwarz (1983) Histochemistry of complex carbohydrates in the skin of the pig snout, with special reference to eccrine glands. Acta Anat 115: 141-150.

Tsukise, A., O. Fujimori, K. Yamada (1988) Histochemistry of glycoconjugates in the goat nasolabial skin with special reference to eccrine glands. Acta Anat 132: 150-158.

Walsh, T.J., A. Martinez, J. Peter, M.J. Miller, E. Unsworth, F. Cuttitta (1996) Antimicrobial activity of adrenomedullin and its gene related peptides. The Infectious Diseases Society of America (IDSA). Annu Meet, p 792.

Welsch, U., G. van Dyk, D. Moss, F. Feuerhake (1998a) Cutaneous glands of male and female impalas (Aepyceros melampus): Seasonal activity changes and secretory mechanisms. Cell Tissue Res 292: 377-394.

Welsch, U., F. Feuerhake, R. van Aarde, W. Buchheim, S. Patton (1998b) Histo- and cytophysiology of the lactating mammary gland of the African elephant (Loxodonta africana). Cell Tissue Res 294: 485-501.

Wollina, U., H. Schaarschmidt, C. Hipler, B. Knopf (1989) Distribution of glycoconjugates in human skin appendages. Acta Histochem 87: 87-93.

Wollina, U. (1990a) Immunohistochemical investigations in epidermal Merkel cells - A common phenotype with eccrine sweat epithelium. Acta Histochem 88: 47-50.

Wollina, U., H. Schaarschmidt, B. Knopf (1990b) Immunolocalization of cytokeratins in human eccrine sweat glands. Acta Histochem 88: 125129. 